\title{
Mechanical Properties Characterization of Composite Sandwich Materials Intended for Space Antenna Applications
}

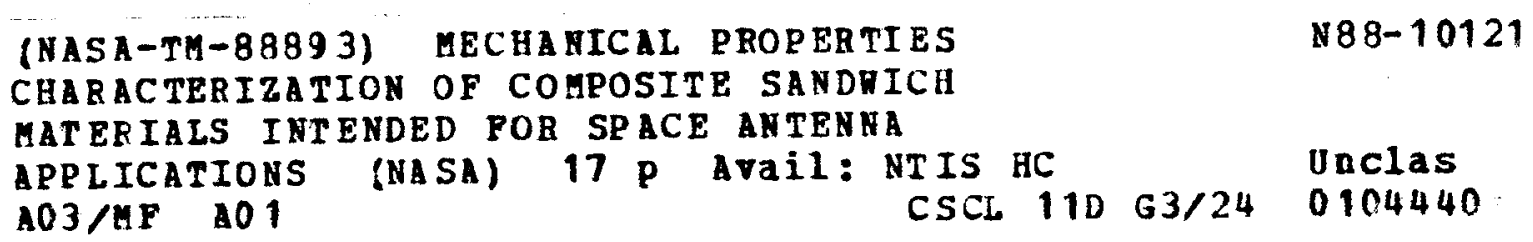

Kenneth J. Bowles and Raymond D. Vannucci

Lewis Research Center

Cleveland, Ohio

Prepared for the

Test Methods and Design Allowables for Fiber Composites:

Second Symposium

sponsored by the American Society for Testing and Materials

Phoenix, Arizona, November 3-4, 1986 



\title{
MECHANICAL PROPERTIES CHARACTERIZATION OF COMPOSITE SANDWICH
}

\author{
MATERIALS INTENDED FOR SPACE ANTENNA APPLICATIONS \\ Kenneth J. Bowles and Raymond D. Vannucci \\ National Aeronautics and Space Administration \\ Lewis Research Center \\ Cleveland, Ohio 44135
}

\section{SUMMARY}

The composite material proposed for use in the Advanced Communications Technology Satellite (ACTS) Program contains a new, high-modulus graphite fiber as the reinforcement. A study was conducted to measure certain mechanical properties of the new fiber-reinforced material as well as of a composite-faced aluminum honeycomb sandwich structure. Properties were measured at $-157,22$, and $121^{\circ} \mathrm{C}$. Complete characterization of this material was not intended.

Longitudinal tensile, picture-frame shear, short-beam shear, and flexural tests were performed on specimens of the composite face-sheet materials. Unidirectional, cross-plied, and quasi-isotropic fiber composite ply layup designs were fabricated and tested. These designs had been studied by using NASA's Integrated Composite Analyzer (ICAN) computer program. Flexural tests were conducted on $\left[ \pm 60^{\circ} / 0^{\circ}\right]_{s}$ composite-faced sandwich structure material. Resistance strain gages were used to measure strains in the tenslle, picture-frame, and sandwich flexural tests.

The sandwich flexural strength was limited by the core strength at -157 and $22{ }^{\circ} \mathrm{C}$. The adhesive bond strength was the 1 imiting factor at $121^{\circ} \mathrm{C}$. Adhesive mechanical properties are reflected in sandwich structure flexural properties when the span-to-depth ratio is great enough to allow a significant shear effect on the load-deflection behavior of the sandwich beam. Most measured properties agreed satisfactorily with the properties predicted by ICAN.

\section{INTRODUCTION}

A common use for composites in space has been as antenna reflector structures. An antenna structure is weight critical and requires high stiffness and dimensional stability over a temperature range of -157 to $121^{\circ} \mathrm{C}$. One such structure is under development for the Advanced Communications Technology Satellite (ACTS). The study reported herein is concerned with characterizing the materials proposed as components for this structure. A polymer-matrix, graphite-fiber-reinforced composite sandwich structure was selected to meet the general antenna requirements. An ultra-high-modulus graphite fiber (Thornel P-75 pitch-based fiber) was chosen as the reinforcement for the sandwich face sheets. These fibers are normally characterized by low thermal expansion values. The weight-critical requirement was met by using sandwich construction with thin composite face sheets. Aluminum honeycomb is generally used as the sandwich core (ref. 1) because it possesses desirable properties such as 


\section{(1) Satisfactory shear properties}

(2) High thermal conductivity that allows good transfer of heat from one face sheet to the other

(3) Easy formability and machinability

(4) Sufficient electrical conductivity to meet grounding requirements

The polymer matrix is a high-temperature epoxy known as Fiberite 934, suitable for use to $177^{\circ} \mathrm{C}$. Properties of the three sandwich constituents and the adhesive are tabulated in table 1.

A computer program has been developed at the Lewis Research Center to confirm the structural design data. Called Integrated Composite Analyzer (ICAN) (ref. 2), it analyzes and designs fiber composite structures. The data generated by this computer program were compared with data from a series of mechanical tests at $-157,22$, and $121^{\circ} \mathrm{C}$. A matrix of the test program is given in table II. The test battery, the results, and observations are discussed herein. Although the materials selected for the ACTS program were changed during the course of this work, the materials tested were not changed because the major objective of this work was to confirm ICAN predictions. Some of the measured data are compared with ICAN predictions.

\section{SYMBOLS}

c thickness of honeycomb core

D flexural rigidity

Ef face-sheet modulus

$E_{11, t}$ Young's modulus

G shear modulus

$\mathrm{G}_{\mathrm{C}}$ shear modulus of honeycomb core

$h$ distance between face-sheet centroids $(t+c)$

L span

$\ell^{*} \quad$ sandwich critical length

P flexural load

Q shear stiffness

$T_{g}$ glass transition temperature

$t_{f}$ face-sheet thickness

$\Delta \quad$ total beam deflection 


$\begin{array}{ll}v & \text { Poisson's ratio } \\ \sigma 11, f \text { flexural strength, } 11 \text { direction } \\ \sigma 11, t \text { tensile strength, } 11 \text { direction } \\ \tau & \text { shear strength }\end{array}$

MATERIALS AND FABRICATION PROCEDURES

The laminated composite sheet materials evaluated in this investigation were fabricated from $0.013-\mathrm{cm}(0.005-\mathrm{in}$.$) and 0.0063-\mathrm{cm}(0.0025-\mathrm{in}$.$) thick$ P-75/934 epoxy unidirectional prepreg tape. The laminates were given a final autoclave cure at $177^{\circ} \mathrm{C}$ under $6.9 \times 10^{3} \mathrm{~Pa}(100 \mathrm{psi})$ for $2 \mathrm{hr}$ according to the manufacturer's recommended processing procedure. The fiber content of the cured laminates was 62 to 63 vol $\%$. The properties of the constituent materials are presented in table I. Fiber properties were assumed to remain constant over the temperature range studied, and changes in matrix properties were computed by subprograms built into ICAN.

Both unidirectional and angle-plied laminates from 4 to 8 plies thick (table II) were fabricated and tested for tensile, flexure, shear, and shortbeam shear properties. Sandwich panels were prepared by using a roomtemperature-curing epoxy adhesive (McCann 580-5) bond cured $\left[ \pm 60^{\circ} / 0^{\circ}\right]_{5}$ face sheets to $0.64-\mathrm{cm}(0.25-\mathrm{in}$.$) thick aluminum honeycomb (Hexcel 1/4-5052-0.0007)$ with a density of $0.026 \mathrm{~g} / \mathrm{cm}^{3}$ and a $0.64-\mathrm{cm}(0.25-\mathrm{in}$.$) cell size. The proper-$ ties of the adhesive and the honeycomb are given in table I. Although the adhesive was cured at room temperature, the measured $T_{g}$ was $177^{\circ} \mathrm{C}$. Tests on single lap-shear aluminum specimens (table III) showed that the adhesive retained 60 percent of its room-temperature lap-shear strength at $121^{\circ} \mathrm{C}$. The specimens measured $2.5 \mathrm{~cm}(1.0 \mathrm{in.})$ wide by $17.8 \mathrm{~cm}(7.0 \mathrm{in.})$ long by $0.32 \mathrm{~cm}$ (0.125 in.) thick. The overlap was $1.3 \mathrm{~cm}(0.5 \mathrm{in.})$.

\section{TEST METHODS}

Tensile Tests

All tensile tests were conducted on straight-sided coupons measuring $25.0 \mathrm{~cm}$ ( $10.0 \mathrm{in.})$ long by $1.3 \mathrm{~cm}$ ( $0.5 \mathrm{in.}$ ) wide by approximately $0.23 \mathrm{~cm}$ ( 0.09 in.) thick. The ends were tabbed with fiberglass-reinforced tabs $6.4 \mathrm{~cm}$ ( $2.5 \mathrm{in.})$ long by $0.10 \mathrm{~cm}(0.04 \mathrm{in.})$ thick. All tensile specimens were instrumented with back-to-back strain gages in both the longitudinal and transverse directions. The strains were measured by using a network of signal conditioners and amplifier bridges. The strain data were confirmed by a series of tests that measured the initial moduli and Poisson's ratios on a Budd portable strain indicator with a switch and balance unit. The specimens were stressed with an Instron tensile test machine (model 1125). All tests were run at a strain rate of $0.13 \mathrm{~cm} / \mathrm{min}(0.05 \mathrm{in} . / \mathrm{min})$. 


\section{Picture-Frame Tests}

The picture-frame test was selected to measure shear properties because (1) the test involves in-plane shear properties, (2) the in-plane load is placed uniformly on the edges, (3) the test can be adapted for different temperatures, and (4) the shear properties are measured on a panel rather than a small specimen. The specimens (fig. 1) were instrumented with strain gages (back to back) at the points indicated. They were mounted in these positions to monitor the specimen for any buckling that might occur during loading and to map the strains across it. The tests were run at a strain rate of $0.13 \mathrm{~cm} / \mathrm{min}(0.05 \mathrm{in.} / \mathrm{min})$.

\section{Sandwich Flexural Tests}

Three-point flexural tests were conducted on specimens of the composite sandwich structure measuring $25.4 \mathrm{~cm}(10.0 \mathrm{in.})$ long by $5.1 \mathrm{~cm}(2.0 \mathrm{in}$.$) wide$ by approximately 0.64 ( $0.25 \mathrm{in.})$ thick. Load spreaders measuring $2.54 \mathrm{~cm}$ ( 1.0 in.) wide by $5.1 \mathrm{~cm}(2.0 \mathrm{in.})$ long by $0.64 \mathrm{~cm}(0.25 \mathrm{in.})$ thick were used at the point of loading and at the two support points to prevent localized compressive failure at these points. Strain gages were bonded at the sites shown in figure 2. A dial gage under the point of loading was used to measure the deflections. The crosshead speed was adjusted to give a surface fiber strain rate of $0.13 \mathrm{~cm} / \mathrm{min}(0.05 \mathrm{in} . / \mathrm{min})$. A series of tests were run to failure on specimens with a 25.4-cm (10.0-in.) span. Another series of tests were run using five different spans to measure the flexural properties of the sandwich structures. These tests were not run to failure.

\section{Composite Three-Point Bend Tests}

Both standard flexural and short-beam shear tests were conducted on unidirectional P-75/934 composite specimens as described in ASTM D-790 and ASTM D-2344, respectively. The span-to-depth ratlo for the short-beam shear tests was 5 . The center loading rate for both tests was $0.13 \mathrm{~cm} / \mathrm{min}$ $(0.05 \mathrm{in.} / \mathrm{min})$. Testing was done at all three temperatures.

\section{RESULTS}

\section{Tensile Tests}

The results of the tensile tests are presented in table IV. The failure stresses, failure strains, elastic moduli, and Poisson's ratios are tabulated for each ply layup scheme at the three test temperatures. Typical failure fractures are shown in figure 3 . The fact that the breaks were across the width of the specimens and away from the end tabs indicated reliable test results. The measured room-temperature tensile properties are in good agreement with those calculated from the ICAN program (table V). Calculated values of strength and moduli at the two extreme temperatures differed from the roomtemperature values by less than 1 percent and are not included in the table. 


\section{Sandwich Three-Point-Bend Tests}

Two different sets of sandwich structure specimens, both with the

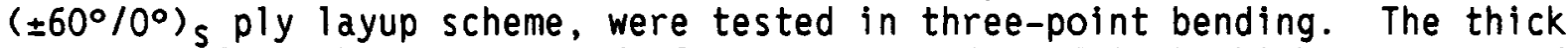
composite face sheets were made from $0.013-\mathrm{cm}(0.005-i n$.$) thick prepreg and$ measured $0.089 \mathrm{~cm}(0.035 \mathrm{in.})$ in thickness. The thin composite face sheets were prepared from $0.0064-\mathrm{cm}(0.0025-i n$.$) thick prepreg (six plies) and meas-$ ured $0.028 \mathrm{~cm}(0.011 \mathrm{in.})$ in thickness. As can be seen from the data in table VI, the maximum stresses in the face sheets of the thick specimens were between 72 and $89 \mathrm{MPa}(10$ and $13 \mathrm{ksi})$. Table IV lists the room-temperature failure strength of the $\left[ \pm 60 / 0^{\circ}\right]_{s}$ thick composites as $331 \mathrm{MPa}$ (48 ksi). The face sheets were stressed to only 25 percent of their fallure stress. The failures in the sandwich specimens occurred either by crippling in the aluminum honeycomb itself or by debonding in the adhesive/honeycomb interface. The crippling failures appeared to be either the crushing of the honeycomb under the load spreader ( $f i g .4$ ) or a shear type of compressive failure near the support pads (fig. 5). These fallures occurred at the two lower temperatures. At $121^{\circ} \mathrm{C}$, the failure occurred at the honeycomb/face-sheet interface at the ends of the sandwich specimens. The stresses within the thin composite face sheets were higher, almost $132 \mathrm{MPa}$ ( $19 \mathrm{ksi})$, and failure still occurred within the honeycomb. The stress levels within the face sheets were still well below the failure stress. Strain data from the gages on both surfaces of the specimens indicated that no twisting or unusual deformation occurred during testing.

When a beam is deflected under three-point loading by a central load transverse to its thickness, the relationship between the deflection and the load is

$$
\Delta=\frac{P L^{3}}{48 D}+\frac{P L}{4 Q}
$$

The first term on the right side of the equation denotes the amount of the deflection that is caused by the bending reaction of the beam. The second term on the right denotes that part of the total deflection that is caused by the shear reaction. Upon rearranging, the equation becomes

$$
\frac{\Delta}{P L}=\frac{L^{2}}{48 D}+\frac{1}{4 Q}
$$

If one measures beam deflections at different loads while varying the span, the data can then be plotted on rectangular paper in the form of $\Delta / P L$ against $L^{2}$, with the slope $1 / 48 D$ and the intercept 1/4Q. Eight measurements were made at five spans ranging from 15.2 to $27.9 \mathrm{~cm}(6.0$ to $11.0 \mathrm{in}$.). The points were fitted to a linear curve by regression analysis for each specimen at the three temperatures.

The flexural rigidity and the shear stiffness can also be calculated from the following two equations:

$$
D=\frac{E_{f} t_{f} h^{2}}{2\left(1-v^{2}\right)}
$$




$$
Q=h G_{C}
$$

The measured and calculated values of $D$ agreed at all three temperatures for both types of composite sandwiches. The only measured values not in agreement with calculated values were those of $Q$ at $121^{\circ} \mathrm{C}$.

Using the measured face-sheet moduli from table VI in equation (3), we calculated the flexural rigidity of the thick-and thin-faced sandwiches to be $42.8 \mathrm{MPa} / \mathrm{cm}(15.8 \mathrm{ksi} / \mathrm{in}$.$) and 23.6 \mathrm{MPa} / \mathrm{cm}(8.7 \mathrm{ksi} / \mathrm{in}$.$) , respectively. Since$ the calculation included only the flexural modulus of the composite, no significant change was expected in the values of $D$ over the temperature range studied. The bending moduli from table VI agree with Young's moduli in table IV. One would normally expect the bending modulus to be slightly lower than Young's modulus.

The calculation of $Q$, as shown in equation (4), is quite simple. By using the shear modulus value of $75.8 \mathrm{kPa}$ ( $11 \mathrm{psi}$ ) from table I, the shear stiffnesses can easily be calculated. The values are $5.7 \mathrm{MPa} / \mathrm{cm}(2.9 \mathrm{ksi} / \mathrm{in}$.) for the thin-faced sandwich and $8.4 \mathrm{MPa} / \mathrm{cm}(3.1 \mathrm{ksi} / \mathrm{in}$.$) for the thick-faced$ sandwich. The agreement is good except for the values of $Q$ measured at $121^{\circ} \mathrm{C}$.

The values for the critical lengths $\ell^{*}$ were calculated from the relationship (ref. 3)

$$
\ell^{*}=10\left(\frac{D}{Q}\right)^{1 / 2}
$$

\section{Composite Three-Point-Bend Tests}

The results of the short-beam shear tests and the three-point-bend (flexural) tests are presented in table VII. No bearing or compressive failures were observed in any of the falled short-beam shear specimens. All flexural specimen failures were caused by fiber breakage on the specimen surface under tension.

\section{Picture-Frame Tests}

The picture-frame tests consumed a major portion of the total test time. For the tests at $121^{\circ} \mathrm{C}$, the metal picture frame was initially bonded to the composite with a $177{ }^{\circ} \mathrm{C}$ curing adhesive. The differences in thermal expansion between the metal frame and the composite specimen caused the sample to "oil can" within the frame during the cooldown from the cure temperature to room temperature. The high-temperature-curing adhesive was replaced with a roomtemperature-curing adhesive for the specimen tested at room temperature. The $121{ }^{\circ} \mathrm{C}$ testing was repeated with the metal picture frame bolted to the test specimen. The final torquing of the bolts was done at the test temperature. The low-temperature testing was done with the metal picture frame bolted to the test specimen. One possible means of eliminating the problems caused by the difference in the coefficient of thermal expansion values between the specimen and the picture frame may be to make the specimen and the picture frame into 
one integral unit from the composite material being tested. This may cause problems in fabrication and load transfer, but these problems may be solvable.

When this test fixture was used with strain gages, the strain measurement varied from the corner of the specimen inward toward the center along the horizontal (compressively loaded) diagonal. At the center, the tensile strain (in line with the load, fig. 1) and the compression strain were almost identical. The suggested positioning of strain gages or a compressometer is about onethird of the diagonal from the end (ref. 4). ASTM D-2719 recommends positioning the strain-measuring device along the tension diagonal. This measures strain data that are numerically equivalent to the compressive strain data at the specimen center. The shear moduli reported herein (table VIII) were calculated from the strains measured at the specimen center. The tension diagonal of the picture-frame specimen is designated as the $0^{\circ}$ direction. A failed specimen is shown in figure 6 . The failure is a vertical break in line with the load axis. This failure mode was caused by a compressive failure of the $60^{\circ}$ fibers.

\section{DISCUSSION}

\section{Tensile Tests}

Both the tensile and flexural properties measured on the face sheets of the sandwich structures were fiber dependent and correlated well with calculate properties from the program ICAN and with each other. The properties of the $\left[ \pm 60 / 0^{\circ}\right]_{s}$ face-sheet material used in this study were large enough to cause the specimen to fail either in the honeycomb or in the adhesive interface. This made the bonding of the face sheets to the aluminum honeycomb a critical step in fabricating the ACTS honeycomb structure used in this study.

\section{Composite Three-Point-Bend Tests}

The two composite three-point-bend tests appeared to show trends contrary to those expected from laminate theory. The data, shown in table VII, indicated that the flexural properties were temperature dependent. From experience, a limited amount of matrix dependence is normally observed in polymer-matrix composite flexure test results. These measured data are in agreement with published vendor data. All failures were determined to be due to fiber breakage on the tensile surface.

The shear strength data from the short-beam shear tests did not show a strong temperature dependence, which would be apparent for a matrix-dependent property. All specimens failed in shear at all temperatures. No bearing failures were observed. Calculated values from ICAN do show a significant drop of $39 \mathrm{kPa}$ ( $5.7 \mathrm{ksi}$ ) over the $278 \mathrm{deg} \mathrm{C}$ temperature range. We cannot explain why matrix effects were suggested in the flexural data but not in the short-beam shear data. Both sets of specimens were machined from the same composite panel. 


\section{Picture-Frame Tests}

Little is available in the literature describing the details and interpreting the results of picture-frame shear tests. The most extensive treatment is presented in reference 5 , which suggests a lack of agreement between the investigators cited. This investigation showed that the compressive strain was not uniform across the horizontal diagonal of the test specimen shown in figure 1. An analysis of the picture-frame test is needed to determine the stress distribution within the test specimen as well as the strain distribution along the compression diagonal. An analysis model has been developed at Lewis, but the detailed results are not yet available.

The room-temperature data measured using the picture-frame shear test were in good agreement with those predicted by the ICAN program. No changes in the shear modulus for the $\left[ \pm 60^{\circ} / 0^{\circ}\right]_{s}$ composite material over the temperature range -157 to $121{ }^{\circ} \mathrm{C}$ were measured by the picture-frame test. The composite shear modulus is significantly influenced by the matrix shear modulus. This property would be expected to be influenced by temperature, decreasing as the temperature increases. Another type of modulus measurement was chosen for general comparison. Dynamic shear moduli measurements were made on $\left[ \pm 60^{\circ} / 0^{\circ}\right]_{S}$ composite specimens. The strain was 0.1 percent at a cycle of $1 \mathrm{rad} / \mathrm{sec}$. The results indicated no noticeable change in the dynamic shear moduli of the $\left[ \pm 60^{\circ} / 0^{\circ}\right]_{\mathrm{S}}$ specimen over the temperature range -157 to $121^{\circ} \mathrm{C}$.

The failure mode in the picture-frame tests should be explained in somewhat more detail. All failures were compressive failures along the tension diagonal of the specimen (the axis of loading). One test was run on a specimen that was bonded to the metal frame with an adhesive cured at room temperature. The test was conducted at $-157^{\circ} \mathrm{C}$. The cooling to $179 \mathrm{deg} \mathrm{C}$ below the cure temperature caused the specimen to "oil can" within the metal frame. That test resulted in a flexural failure parallel to the tension diagonal but offset about halfway between the diagonal and the side corner. Although only one test was run, that result, along with the strain gage data indicating that no oil canning occurred in the other tests, indicates that the coefficient of thermal expansion mismatch between the composite and the metal frame was of no consequence in these tests. None of the failures were offset from the tension diagonal.

\section{Sandwich Three-Point-Bend Tests}

The flexural tests of the sandwich structures contributed significantly to the information gleaned from this study. A series of low-load tests were conducted to measure the flexural rigidity $D$ and the shear stiffness $Q$ of the sandwich panels. Those properties can determine the dimensional requirements for controlling the reaction of the honeycomb sandwich to transverse loading. These low-load flexural tests also confirmed the moduli. As expected, the flexural modulus was relatively insensitive to temperature variations because the matrix modulus was so much lower than the fiber modulus.

The shear stiffness determined by multiplying the core modulus by the distance between the centroids of the sandwich face sheets was relatively unchanged between -157 and $22^{\circ} \mathrm{C}$. At $121^{\circ} \mathrm{C}$, however, the shear stiffness dropped to approximately 45 percent of its room-temperature value. The modulus of the aluminum core was $75.8 \mathrm{kPa}(11 \mathrm{psi})$, from table I. Young's modulus 
of the 5052 aluminum alloy at $121^{\circ} \mathrm{C}$ was about the same as its room-temperature value (according to the ALCOA aluminum handbook (1959, p. 30)). It can be inferred from table VIII that the shear modulus of the $\left[ \pm 60^{\circ} / 0^{\circ}\right]_{s}$ composite does not change with increasing temperature. As previously noted (in the section Materials and Fabrication Procedures), the epoxy adhesive used to bond the face sheets to the aluminum honeycomb retained approximately 60 percent of its room-temperature mechanical strength at $121^{\circ} \mathrm{C}$. This change in the mechanical properties of the adhesive could explain the variability of the shear stiffness. Of the three sandwich constituents, the adhesive is the only material known to exhibit a decrease in mechanical properties at $121^{\circ} \mathrm{C}$.

Under these test conditions, the contribution of the developed shear forces to the deflection of the sandwich structure was large. Shearing contributed about two-thirds of the total deflection of the sandwich material with the thicker face sheets. For the thinner-faced sandwich, this value decreased to approximately 55 percent. The critical lengths listed in table VI are the minimum lengths needed to eliminate shearing effects. The strong effect of the shearing stresses on the structures is reflected in the failure modes described previously.

\section{SUMMARY OF RESULTS}

A study of the mechanical properties of composite sandwich materials intended for antenna applications on the Advanced Communications Technology Satellite (ACTS) led to the following conclusions:

1. The ICAN program appears to be effective in predicting both fiberdominated and matrix-dominated mechanical properties of composite materials.

2. The picture-frame test can be used to measure shear properties that are in line with predicted values and also to determine whether the resulting failure modes are those predicted. It is recommended that a detailed analysis of the test be made to clarify conflicting information found in the literature. Those who might want to use this test as a part of a standard characterization program might consider combining the specimen and the loading frame into one unit using one construction material. This would eliminate the natural concern about the effects of differences in the coefficients of thermal expansion. However, the problem of introducing the load into the unit may be too great.

3. The sandwich flexural tests highlight the significance of the mechanical properties of the adhesive in producing a composite sandwich structure that exhibits all the intended properties. The mechanical properties of the adhesive are especially important in structures with short span-to-thickness ratios, where the shear stiffness contributes to the magnitude of the beam or panel deflection.

4. The sandwich composite flexural tests employed span lengths less than the critical lengths of the two types of sandwiches used in this study. This produced fallure mechanisms that were controlled by shear reactions in the honeycomb and the adhesive. At span lengths greater than the critical lengths, the failure modes would be expected to be flexure controlled. 


\section{REFERENCES}

1. Stonier, R.A., in Technology Transfer, 13th National SAMPE Technical Conference Proceedings, SAMPE, Azusa, Ca, 1981, pp. 203-217.

2. Murthy, P.L.N., and Chamis, C.C., Journal of Composites Technology and Research, Vol. 8, No. 1, Spring 1986, pp. 8-17.

3. Johnson, A.F., and Sims, G.D., Composites, Vol. 17, No. 4, Oct. 1986, pp. $321-328$.

4. Dastin, S., Lubin, G., Munyak, J., and Slobodzinski, A., in Composite Materials: Testing and Design, ASTM STP-460, ASTM, Philadelphia, 1969, pp. 13-26.

5. Lee, S., and Munro, M., Composites, Vol. 17, No. 1, Jan. 1986, pp. 13-22.

TABLE I. - MATERIAL PROPERTIES

\begin{tabular}{|c|c|c|c|c|}
\hline Property & $\begin{array}{l}\text { Fiberite } 934 \\
\text { epoxy resin } \\
\text { at } 24{ }^{\circ} \mathrm{C}\end{array}$ & $\begin{array}{l}\text { Thornel P-75 } \\
\text { carbon fiber } \\
\text { at } 22{ }^{\circ} \mathrm{C}\end{array}$ & $\begin{array}{c}\text { McCann } 580-5 \\
\text { epoxy adhes ive } \\
\text { at } 24{ }^{\circ} \mathrm{C}\end{array}$ & $\begin{array}{l}\text { Hexcel } 5052 \\
\text { hexagonal } \\
\text { aluminum } \\
\text { honeycomb }\end{array}$ \\
\hline $\begin{array}{l}\text { Coefficient of thermal } \\
\text { expansion, ppm }{ }^{\circ} \mathrm{C} \text { : } \\
\text { In the i directiona } \\
\text { In the } 2 \text { directiona } \\
\text { Compression strength, MPa (ksi) } \\
\text { Stabilized compression } \\
\text { strength, MPa (ksi) } \\
\text { Compression modulus } \\
\text { (stabilized), kPa (psi) } \\
\text { Crushing streggth, kPa (psi) } \\
\left.\text { Density, g/cm (lb/in. }{ }^{3}\right) \\
\text { Filament diameter, m (in.) } \\
\text { Plate shear modulus, kPa (psi) } \\
\text { Plate shear strength, kPa (psi) } \\
\text { Poisson's ratio: } \\
\text { In the I directiona } \\
\text { In the two directiona } \\
\text { Shear modulus, GPa (Msi) } \\
\text { Shear strength, MPa (ksi) } \\
\text { Tensile failure strain, percent } \\
\text { Tensile modulus, GPa (Msi) } \\
\text { Tensile strength, MPa (ksi) }\end{array}$ & $\begin{array}{r}65 \times 10^{-6} \\
241.3(35.0) \\
1.22(0.044) \\
1.3(0.185) \\
39.6(13.0) \\
3.9(0.57) \\
103.4(15.0)\end{array}$ & $\begin{array}{r}690\left(\begin{array}{r}10.0 \\
(100)\end{array}\right. \\
10 \times 10^{-6}\left(3.9 \times 10^{2}-6\right) \\
0.25 \\
0.2 \\
0.072) \\
1551(225) \\
(75) \\
(225)\end{array}$ & $\begin{array}{r}102.6 \\
103.4(15.0) \\
1.44(0.052) \\
\end{array}$ & $\begin{array}{r}0.586(0.085) \\
0.655(0.095) \\
137.9(20.0) \\
278.5(40.0) \\
0.026(0.0009) \\
75.8(11.0) \\
344.8(50.0) \\
\\
\end{array}$ \\
\hline
\end{tabular}

$a_{1}$ direction and 2 direction refer to axial direction and radial direction, respectively. 
TABLE II. - ACTS MATERIAL TEST MATRIX

[Temperatures: $-157,22$, and $121^{\circ} \mathrm{C}$.]

\begin{tabular}{|c|c|c|c|}
\hline Type of test & $\begin{array}{c}\text { Number } \\
\text { of tests }\end{array}$ & Ply layup & Desired property \\
\hline Tensile & 5 & $\begin{array}{c}{\left[0^{\circ}\right]_{8},\left[0^{\circ} / 90^{\circ}\right]_{S}} \\
{\left[0^{\circ} / 90^{\circ} \% \pm 45^{\circ}\right]_{S}} \\
{\left[ \pm 60^{\circ} / 0^{\circ}\right]_{S}}\end{array}$ & $\begin{array}{l}\text { Young's modulus, } E_{11, t} \\
\text { tensile strength, } \sigma 11, t \\
\text { Poisson's ratio, } v\end{array}$ \\
\hline Flexure & 5 & {$\left[0^{\circ}\right]_{8}$} & Flexural strength, $\sigma_{11, f}$ \\
\hline Short-beam shear & 5 & {$\left[0^{\circ}\right]_{8}$} & Interlaminar shear strength \\
\hline Picture frame & 2 & $\begin{array}{l}{\left[0^{\circ} / \pm 45^{\circ}\right]_{S}} \\
{\left[ \pm 60^{\circ} / 0^{\circ}\right]_{S}}\end{array}$ & $\begin{array}{l}\text { Shear modulus, } G \text {; shear } \\
\text { strength, } \tau\end{array}$ \\
\hline Sandwich flexure & 3 & {$\left[ \pm 60^{\circ} / 0^{\circ}\right]_{S}$} & $\begin{array}{l}\text { Flexural rigidity, } 0 \text {; shear } \\
\text { stiffness, } Q\end{array}$ \\
\hline
\end{tabular}

TABLE III. - LAP-SHEAR STRENGTH OF MCCANN 580-5 EPOXY ADHESIVE

\begin{tabular}{|l|r|r|r|}
\hline \multirow{2}{*}{} & \multicolumn{3}{|c|}{ Test temperature, ${ }^{\circ} \mathrm{C}$} \\
\cline { 2 - 4 } & -157 & 22 & 121 \\
\hline $\begin{array}{c}\text { Lap-shear strength, } \\
\text { MPa (ksi) }\end{array}$ & $22.9(3.320)$ & $23.0(3.340)$ & $13.7(1.985)$ \\
& $22.1(3.200)$ & $23.5(3.410)$ & $13.2(1.985)$ \\
& $21.4(3.100)$ & $22.1(3.200)$ & $11.9(1.725)$ \\
Arithmetic mean, & $22.8(3.310)$ & $13.7(1.990)$ \\
$\begin{array}{c}\text { MPa (ksi) } \\
\text { Standard deviation, } \\
\text { MPa (ksi) }\end{array}$ & $0.8(0.110)$ & $0.6(0.087)$ & $0.9(0.125)$ \\
\hline
\end{tabular}

TABLE IV. - TENSILE PROPERTIES FOR P-75/934 LAMINATES MEASURED AT DIFFERENT TEMPERATURES

\begin{tabular}{|c|c|c|c|c|c|c|c|c|c|}
\hline \multirow[t]{3}{*}{ Property } & \multicolumn{9}{|c|}{ Ply layup (laminate configuration) } \\
\hline & \multicolumn{3}{|c|}{$\left[0^{\circ}\right]_{8}$} & \multicolumn{3}{|c|}{$\begin{array}{l}{\left[0^{\circ} / 90^{\circ}\right]_{\mathrm{S}}} \\
\text { Temperature, }{ }^{\circ} \mathrm{C}\end{array}$} & \multicolumn{3}{|c|}{$\left[ \pm 60^{\circ} / 0^{\circ}\right]_{S}$} \\
\hline & -157 & 22 & 121 & -157 & 22 & 121 & -157 & 22 & 121 \\
\hline $\begin{array}{l}\text { Failure stress, } \\
\text { MPa (ksi) } \\
\text { Failure strain } \\
\text { Young's modulus } \\
\text { Ell GPa (Msi) } \\
\text { Poisson's ratio, v }\end{array}$ & $\begin{array}{r}848+5.1 \\
(123 \pm 0.7) \\
0 \div 0020 \\
353+2.0 \\
(51.2+0.3) \\
0.304\end{array}$ & $\begin{array}{r}938+1.2 \\
(136+4.2 \\
0.0030 \\
284+1.2 \\
(45.2+T .2) \\
0.300\end{array}$ & $\begin{array}{r}1020+6.0 \\
(148+0.9) \\
0.0030 \\
329+1.3 \\
(47.7+0.2) \\
0.334\end{array}$ & $\begin{array}{r}397+4.8 \\
(57.5 \pm 0.7) \\
0.0020 \\
172+1.0 \\
(25+0.1) \\
0.030\end{array}$ & $\begin{array}{r}415+3.1 \\
(60 \pm 0.4) \\
0.0030 \\
152+0.9 \\
(22+\overline{0} .1) \\
0.040\end{array}$ & $\begin{array}{r}434+3.1 \\
(63 \pm 0.4) \\
0.0030 \\
145+1.6 \\
(21+\overline{0} .2) \\
0.030\end{array}$ & $\begin{array}{r}238+2.1 \\
(34.6 \pm 0.3) \\
0.0020 \\
106+1.4 \\
(15.4+0.2) \\
0.300\end{array}$ & $\begin{array}{r}331+1.5 \\
(48+9.2) \\
0.0030 \\
109+1.9 \\
(15.8+7.9) \\
0.309\end{array}$ & $\begin{array}{r}342+1.7 \\
(49.6+0.2) \\
0.0035 \\
102+2.0 \\
(14.8+0.3) \\
0.295\end{array}$ \\
\hline
\end{tabular}

TABLE V. - ROOM-TEMPERATURE MATERIAL PROPERTIES FOR P-75/934 LAMINATES

\begin{tabular}{|l|r|r|r|r|r|r|}
\hline \multirow{2}{*}{ Property } & \multicolumn{5}{|c|}{ Ply layup (laminate configuration) } \\
\cline { 2 - 7 } & \multicolumn{2}{|c|}{$\left[0^{\circ}\right]_{8}$} & \multicolumn{2}{|c|}{$\left[0^{\circ} / 90^{\circ}\right]_{S}$} & \multicolumn{2}{c|}{$\left[ \pm 60^{\circ} / 0^{\circ}\right]_{S}$} \\
\cline { 2 - 7 } & Experimental & \multicolumn{1}{|c|}{ ICAN } & Experimental & \multicolumn{1}{c|}{ ICAN } & Experimental & \multicolumn{1}{|c|}{ ICAN } \\
\hline $\begin{array}{l}\text { Failure stress, } \\
\text { MPa (ksi) }\end{array}$ & $938(136)$ & $862(125)$ & $415(60)$ & $476(69)$ & $311(48)$ & $324(47)$ \\
$\begin{array}{l}\text { Failure strain } \\
\text { Elastic modulus, } \\
\text { GPa (Msi) }\end{array}$ & 0.0030 & 0.0030 & 0.0028 & 0.0030 & 0.0031 & 0.0030 \\
Poisson's ratio, v & $(41.2)$ & $311(45.2)$ & $152(22.0)$ & $158(23.0)$ & $109(15.8)$ & $109(15.8)$ \\
\end{tabular}


TABLE VI. - FLEXURAL PROPERTIES OF $\left[ \pm 60^{\circ} / 0^{\circ}\right]_{S}$ SANDWICH STRUCTURE

[Poisson's ratio, 0.3.]

\begin{tabular}{|c|c|c|c|c|c|c|}
\hline \multirow[t]{2}{*}{ Property } & \multicolumn{3}{|c|}{ Thick face sheet } & \multicolumn{3}{|c|}{ Thin face sheet } \\
\hline & \multicolumn{6}{|c|}{ Temperature, ${ }^{\circ} \mathrm{C}$} \\
\hline $\begin{array}{l}\text { Face-sheet stress at } \\
\text { failure, MPa (ksi) } \\
\text { Face-sheet bending } \\
\text { modulus, GPa (Msi) } \\
\text { Flexural rigidity, MPa/cm } \\
\text { (ksi/in.) } \\
\text { Shear stiffness, MPa/cm } \\
\text { (ksi/in.) } \\
\text { Critical length, cm (in.) }\end{array}$ & $\begin{array}{r}75.2+4.8 \\
(10.9+0.7) \\
67.6+2.8 \\
(9.8 \pm 0.4) \\
37.7(13.8) \\
6.8(2.5) \\
59.7(23.5)\end{array}$ & $\begin{array}{l}88.8 \pm 11.9 \\
(12.9 \pm 1.7) \\
105.5+5.9 \\
(15.3 \pm 0.8) \\
38.8(14.3) \\
7.55(2.8) \\
57.7(22.7)\end{array}$ & $\begin{array}{r}71.7+7.6 \\
(10.4+7.1) \\
100.6+3.4 \\
(14.6 \pm 0.5) \\
38.5(14.2) \\
3.85(1.4) \\
80.3(31.6)\end{array}$ & $\begin{array}{r}121.4+13.8 \\
(17.6+2.0) \\
89.6+0.7 \\
(13.0 \pm 0.1) \\
24.2(8.9) \\
7.9(2.9) \\
44.4(17.5)\end{array}$ & $\begin{array}{l}132.4+8.3 \\
(19.2+T .2) \\
105.8+6.2 \\
(15.3 \pm 0.9) \\
24.9(9.2) \\
7.55(2.8) \\
46.2(18.2)\end{array}$ & $\begin{array}{r}68.3 \pm 11.9 \\
(9.9+1.7) \\
99.3+4.8 \\
(14.4 \pm 0.7) \\
24.4(9.0) \\
3.6(1.3) \\
66.6(26.0)\end{array}$ \\
\hline
\end{tabular}

TABLE VII. - UNIDIRECTIONAL P-75/934 LAMINATE STRENGTHS

\begin{tabular}{|l|r|r|r|r|}
\hline \multirow{2}{*}{$\begin{array}{c}\text { Test method and } \\
\text { temperature }\end{array}$} & \multicolumn{3}{|c|}{ Experimental } & \multicolumn{2}{c|}{ ICAN } \\
\cline { 2 - 5 } & \multicolumn{4}{|c|}{ Strength } \\
\cline { 2 - 5 } & $\mathrm{kPa}$ & $\mathrm{ksi}$ & $\mathrm{kPa}$ & $\mathrm{ksi}$ \\
\hline Three-point bend: & & & & \\
$-157^{\circ} \mathrm{C}$ & $689 \pm 9.9$ & $100 \pm 1.4$ & 721 & 104.6 \\
$22{ }^{\circ} \mathrm{C}$ & $779 \pm 35$ & $113 \pm 5.1$ & 719 & 104.4 \\
$121{ }^{\circ} \mathrm{C}$ & $633 \pm 24$ & $92 \pm 3.5$ & 718 & 104.2 \\
& & & & \\
Short-beam shear: & $50 \pm 7.3$ & $7.3 \pm 1.1$ & 73 & 10.6 \\
$-157{ }^{\circ} \mathrm{C}$ & $52 \pm 7.0$ & $7.5 \pm 1.0$ & 40 & 5.9 \\
$22{ }^{\circ} \mathrm{C}$ & $53 \pm 2.8$ & $7.7 \pm 0.4$ & 34 & 4.9 \\
$121{ }^{\circ} \mathrm{C}$ & & & \\
\hline
\end{tabular}

TABLE VIII. - SHEAR PROPERTIES OF $\left[ \pm^{6} 60^{\circ} / 0^{\circ}\right]_{S}$ COMPOSITE FROM PICTURE-FRAME IESTS

[Failure mode, compression.]

\begin{tabular}{|c|c|c|c|c|}
\hline \multirow[t]{3}{*}{ Shear property } & & \multicolumn{2}{|c|}{ Test temperature, ${ }^{\circ} \mathrm{C}$} & \\
\hline & \multirow[t]{2}{*}{-157} & \multicolumn{2}{|c|}{22} & \multirow[t]{2}{*}{121} \\
\hline & & Observed & ICAN & \\
\hline $\begin{array}{l}\text { Initial modulus, GPa (Msi) } \\
\text { Shear strength, MPa (Ksi) } \\
\text { Shear strain at failure, percent }\end{array}$ & $\begin{array}{ll}37.7 & (5.47) \\
89.6 & (13.0)\end{array}$ & $\begin{array}{r}37.2(5.4) \\
134.5^{(19.5)} \\
0.47\end{array}$ & $\begin{array}{rr}40.7 & (15.9) \\
(126.8) & (18.4)\end{array}$ & $\begin{array}{r}37.2(5.4) \\
116.2(16.9) \\
0.46\end{array}$ \\
\hline
\end{tabular}




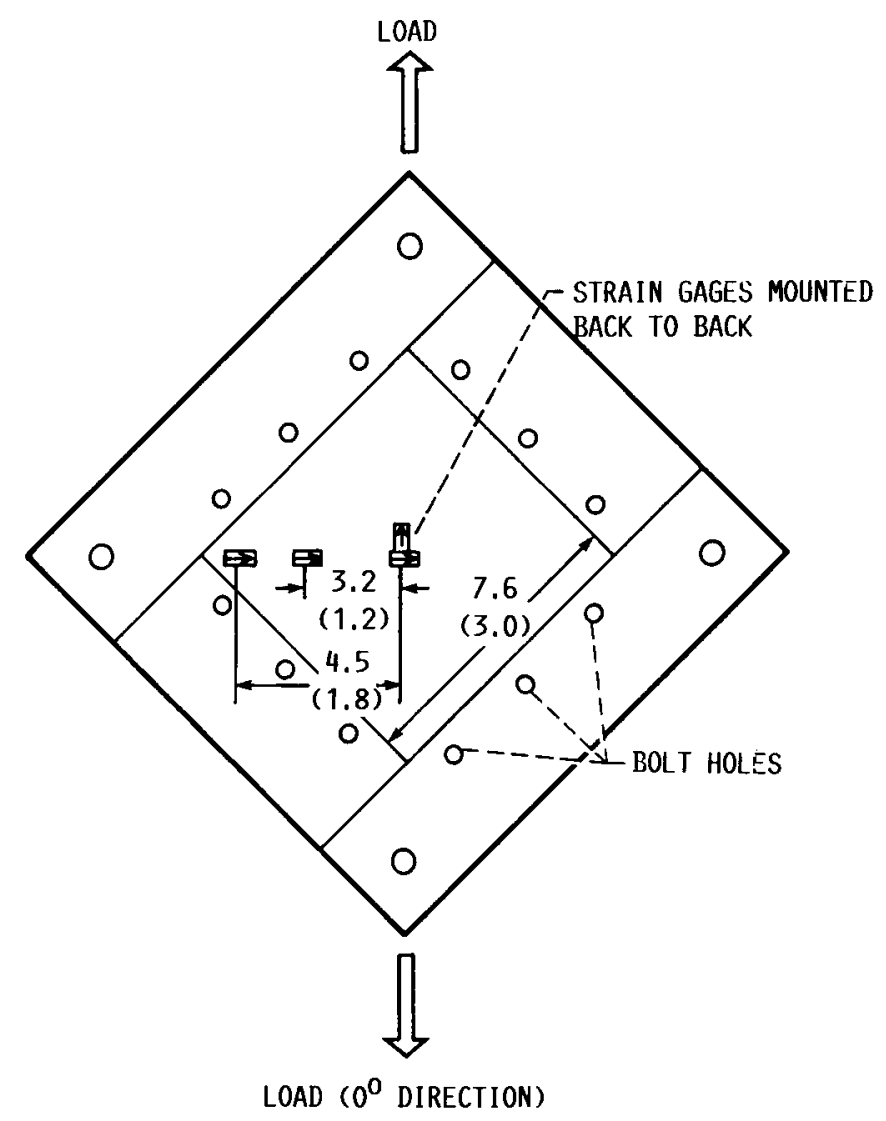

FIGURE 1. - SCHEMATIC OF PICTURE-FRAME SHEAR TEST

SPECIMEN. (DIMENSIONS ARE IN CENTIMETERS (INCHES).)
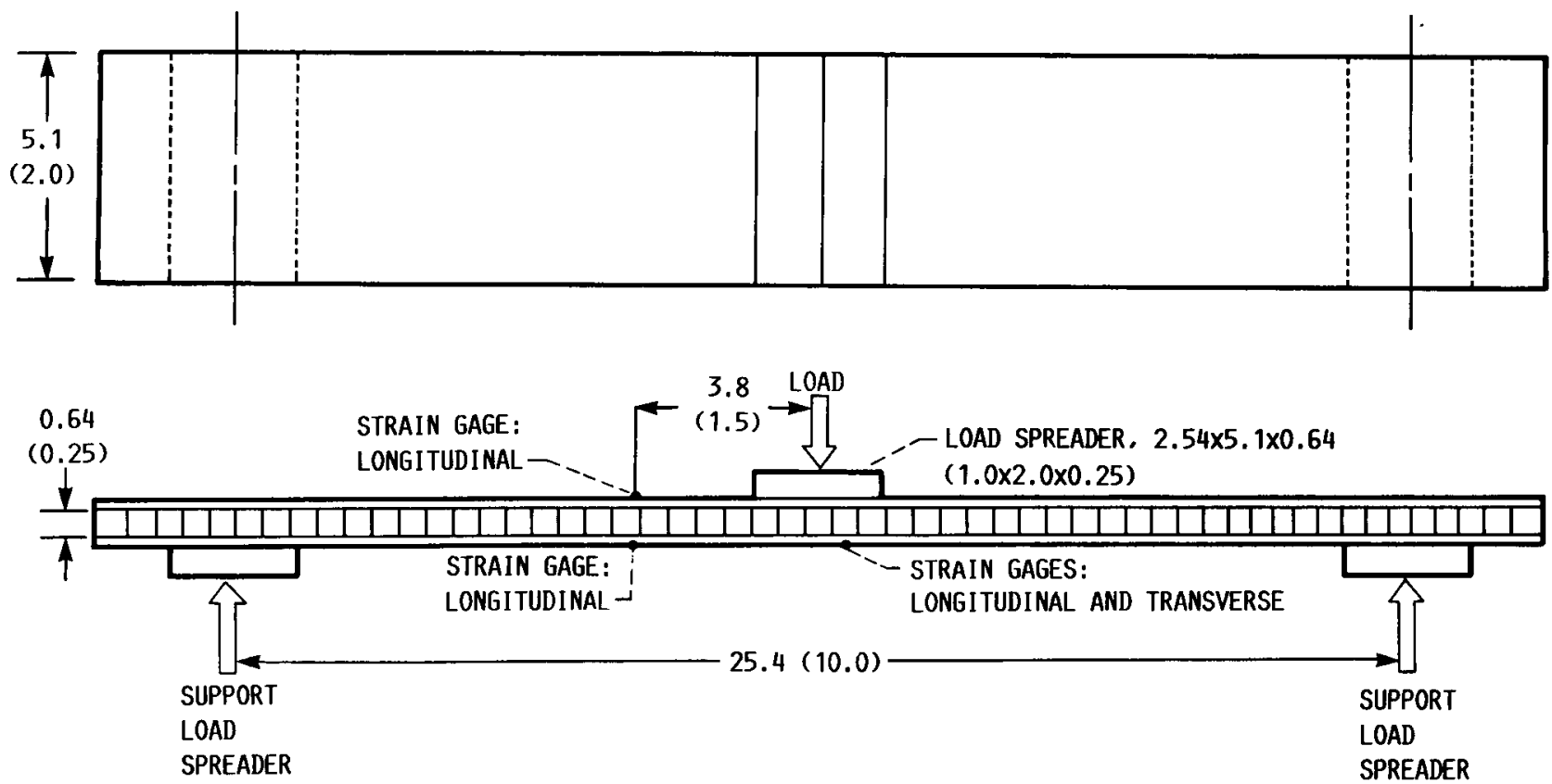

FIGURE 2. - SCHEMATIC OF COMPOSITE SANDWICH FLEXURAL TEST SPECIMEN AND FIXTURE. (DIMENSIONS ARE IN CENTIMETERS (INCHES), ) 
ORIGINAL PAGE IS

OF POOR OTI

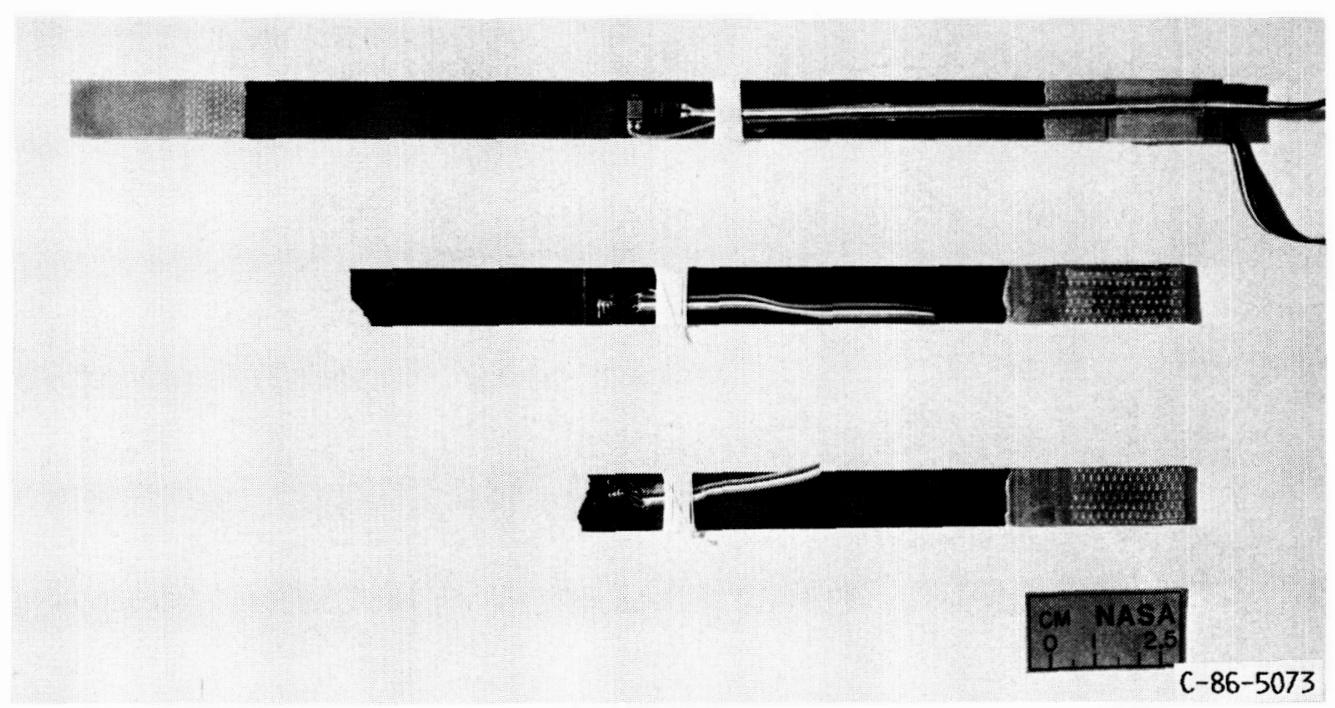

FIGURE 3. - TENSILE SPECIMENS.

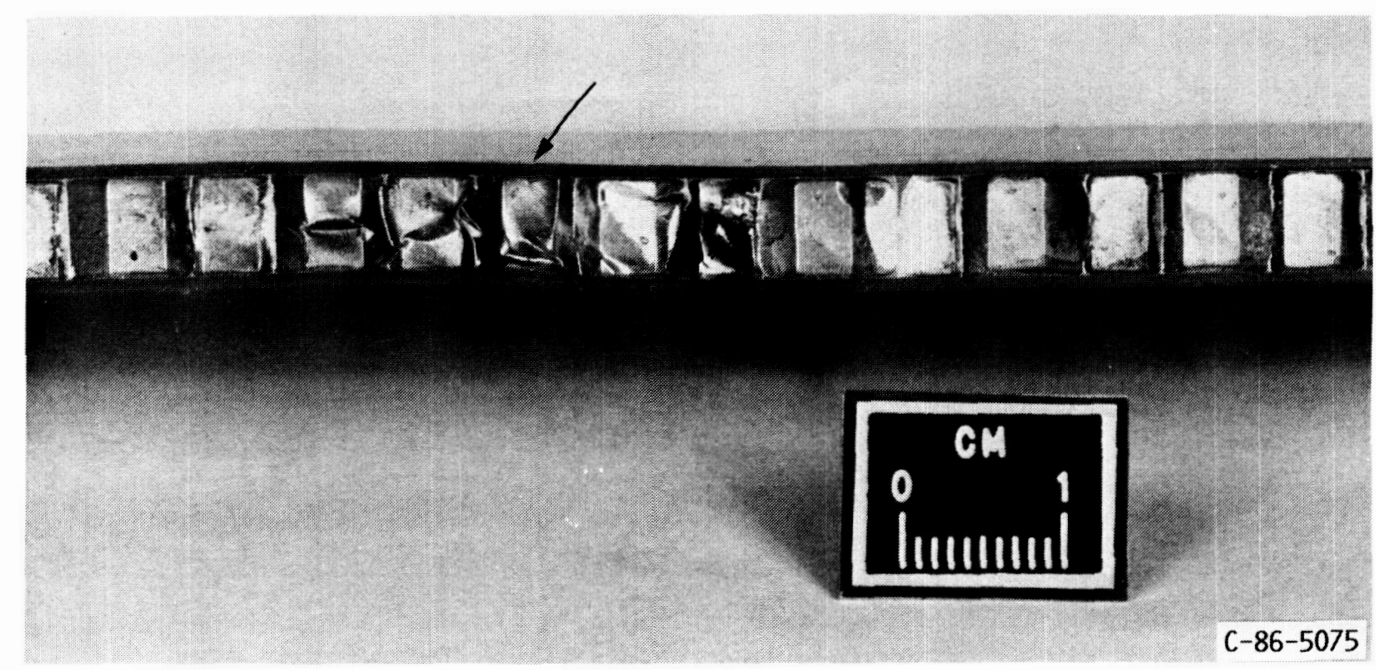

FIGURE 4. - CRIPPLING FAILURE BY LOCALIZED CRUSHING UNDER LOAD SPREADER. 


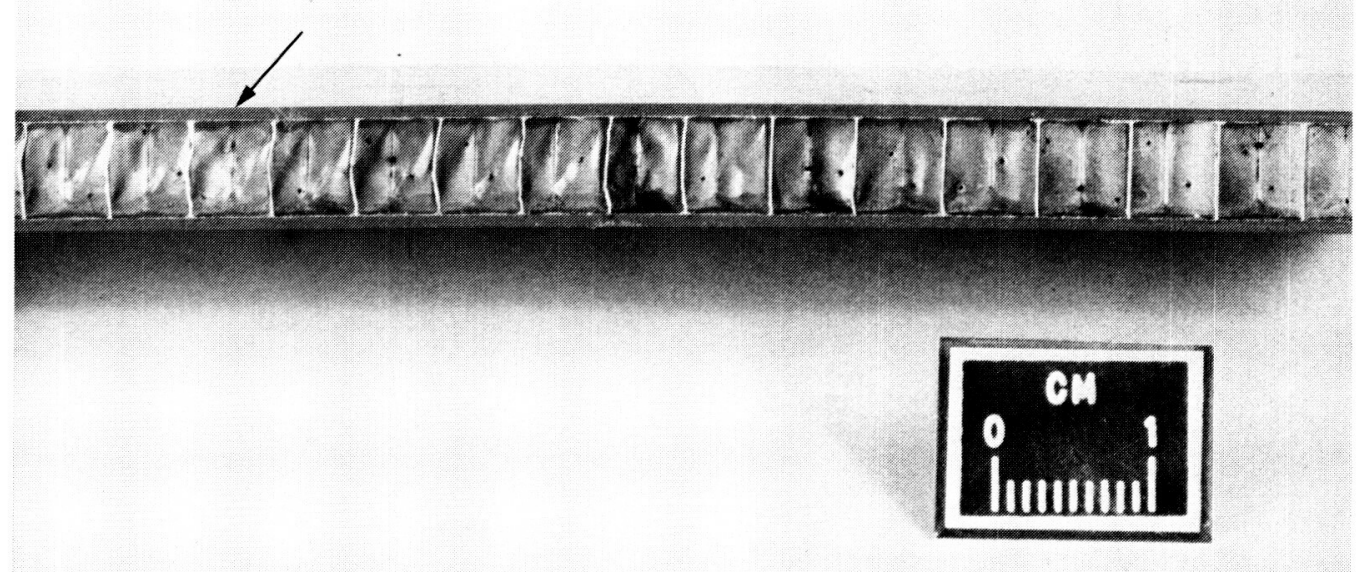

FIGURE 5. - CRIPPLING FAILURE NEAR SUPPORT PADS.

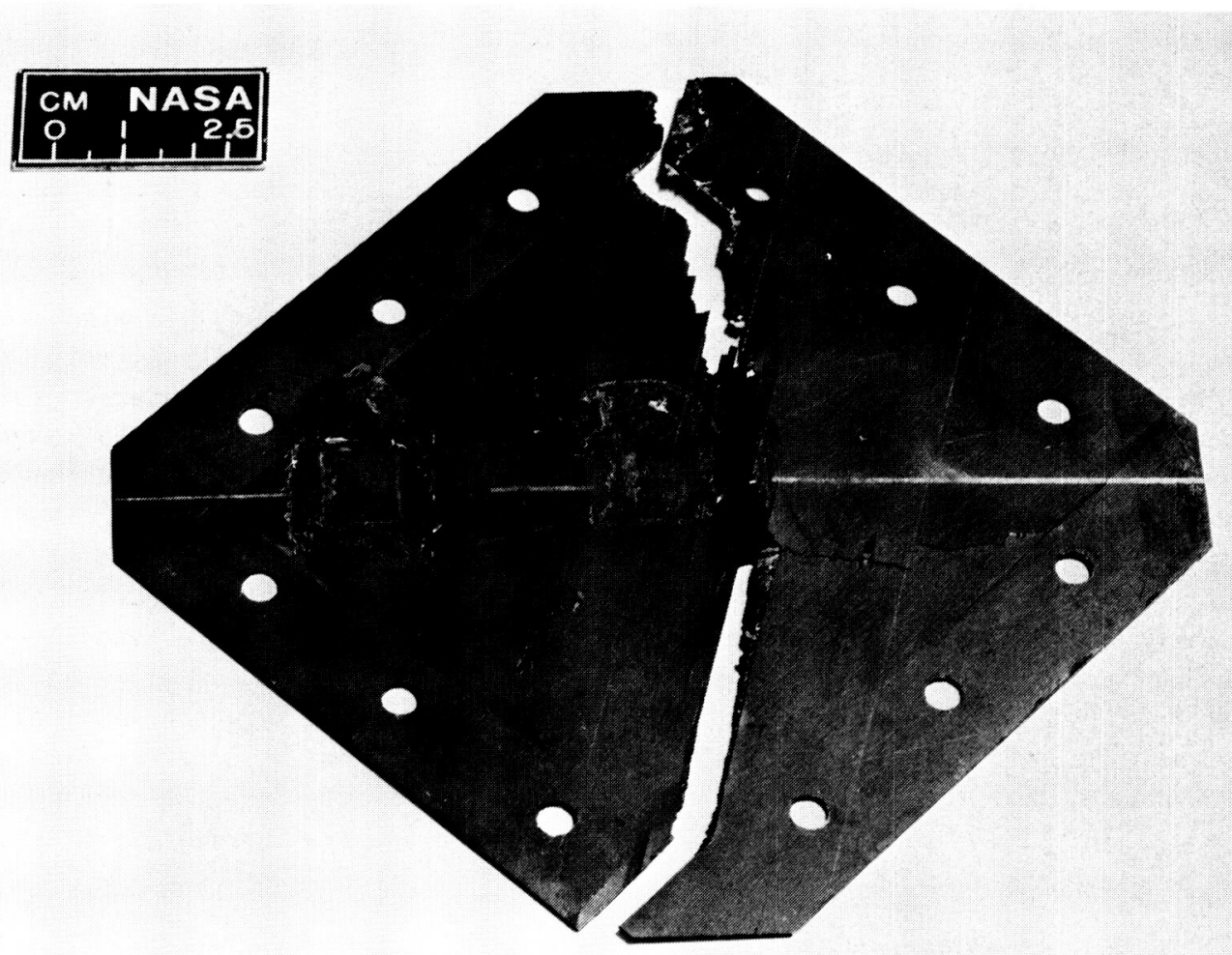

FIGURE 6. - FAILED SPECIMEN FROM PICTURE-FRAME SHEAR TEST. FRACTURE FROM COMPRESSIVE FAILURE IS IN DIRECTION OF TENSILE LOAD. 


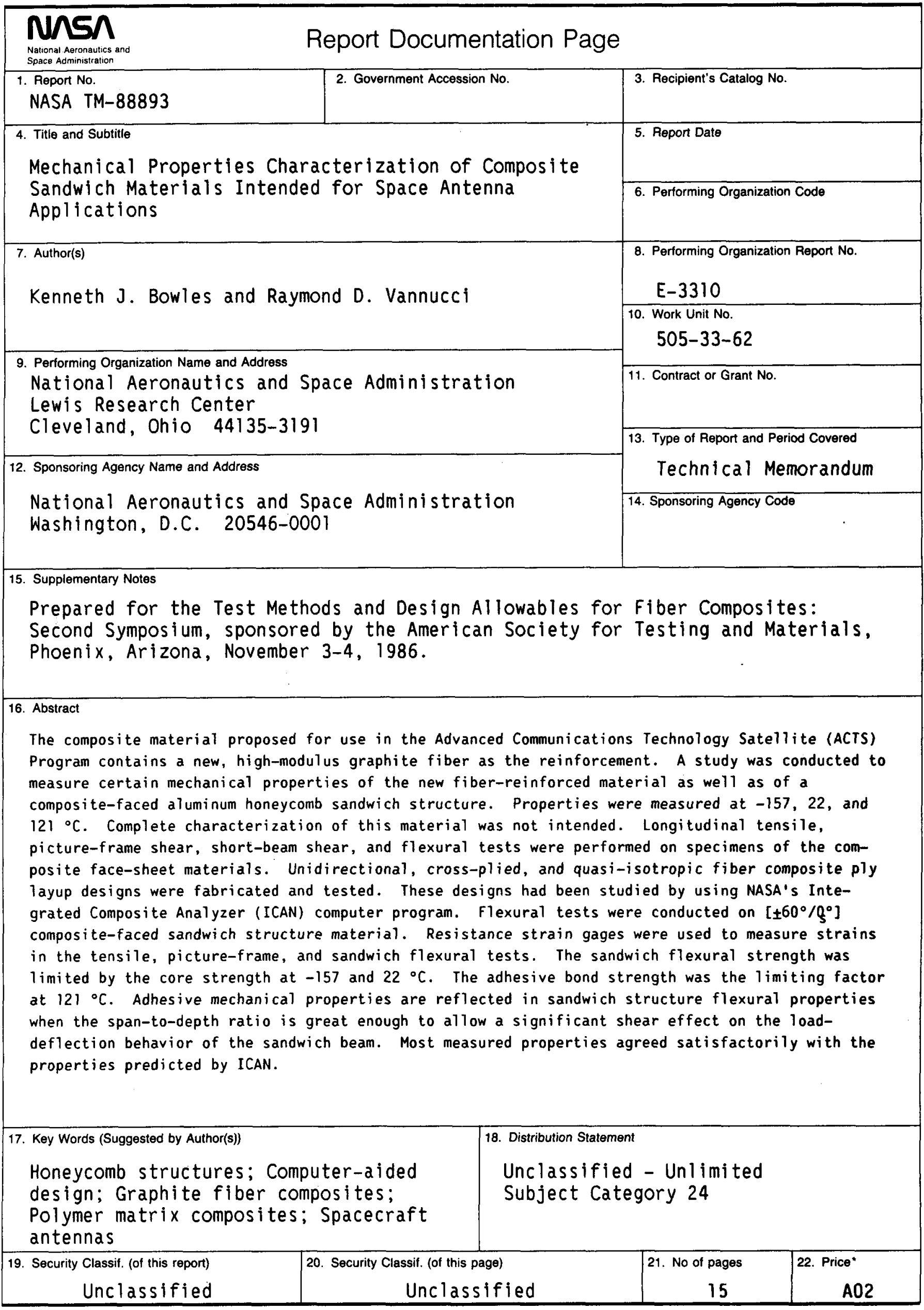

